\title{
MRI FINDINGS IN THE DIAGNOSIS AND MONITORING OF RASMUSSEN'S ENCEPHALITIS
}

\author{
Andréia V. Faria', Fabiano Reis', Guilherme C. Dabus ${ }^{7}$, Verônica A. Zanardi', \\ Marilisa M. Guerreiro², Fernando Cendes².
}

\begin{abstract}
Rasmussen's encephalitis is a devastating syndrome of multifocal brain dysfunction and focal seizures. Magnetic resonance (MR) findings, associated with clinical data and electroencephalogram (EEG), may indicate the diagnosis and could be an indicative of prognosis. We studied 5 patients with Rasmussen's encephalitis, assessing clinical history and MR images. All patients had refractory focal seizures with a predominant motor component associated with hemispheric atrophy, that was proportional to severity of disease and neurological deficits in these patients. Gray and white matter abnormal signal on T2 MR images were found in patients who had hemiparesis. It was not related to the duration of the disease but to aggressiveness. MR proton spectroscopy in severe disease showed lactate and choline increase and decreased NAA, reflecting neuronal and axonal loss, gliosis and elevated membrane turnover and recent - crisis (not controlled). MR studies, in addition to help in diagnosis, may be useful for monitoring metabolic changes and progression of disease in Rasmussen's encephalitis.
\end{abstract}

KEY WORDS: Rasmussen's encephalitis, MRI, spectroscopy, epilepsy.

\section{Achados de RM no diagnóstico e monitorização da encefalite de Rasmussen}

Resumo - A encefalite de Rasmussen é uma devastadora síndrome com disfunção cerebral multifocal e convulsões focais. Achados de ressonância magnética (RM), associados aos dados clínicos e de eletrencefalograma (EEG), podem indicar o diagnóstico e podem ser indicativos de prognóstico. Foram estudados 5 pacientes com encefalite de Rasmussen, avaliando a história clínica e imagens de RM. Todos os pacientes apresentavam crises epilépticas focais refratárias com componente predominantemente motor associadas à atrofia hemisférica, que foi proporcional à gravidade da doença e déficits neurológicos nestes pacientes. Alteração da intensidade de sinal nas substâncias branca e cinzenta, nas sequências ponderadas em $\mathrm{T} 2$, foram encontradas nos pacientes com hemiparesia. Ela não estava relacionada com a duração da doença, mas à severidade. A espectroscopia de prótons por RM na doença severa demonstrou aumento dos níveis de colina e lactato e diminuição de $\mathrm{N}$-acetilaspartato, refletindo perda neuronal e axonal, gliose e aumento de turnover de membrana e crise recente (não controlada). Estudos de RM, além de ajudar no diagnóstico, podem ser úteis para acompanhar alterações metabólicas e progressão da doença na encefalite de Rasmussen.

PALAVRAS-CHAVE: encefalite de Rasmussen, RM, espectroscopia, epilepsia.

The syndrome of chronic encephalitis and intractable focal epilepsy was first reported by Rasmussen in 1958 and consists in severe epilepsy associated with slow progressive neurologic deterioration and progressive lateralized brain destruction'. Previous studies indicated that antiGluR3 autoantibodies might be involved in pathogenesis of the disease ${ }^{2}$. However, other investigators did not find these autoantibodies ${ }^{3}$. More recently, other mechanisms as a cytotoxic T-cell reaction against neurons were dem- onstrated to play a causative role in Rasmussen encephalitis (RE) ${ }^{4}$. Despite the fact that an etiologically significant viral antigen has not yet been found; the early immunosuppressive and antiviral treatment may be effective for a period of time ${ }^{5}$.

Although in rare situations RE may present without epilepsy ${ }^{6}$, seizures mark the clinical features and their severity and evidence of progressive neurological deterioration usually led to early consideration of surgical therapy.

Faculty of Medical Sciences, State University of Campinas (UNICAMP), Campinas SP, Brazil: ${ }^{2}$ Department of Radiology; ${ }^{2}$ Department of Neurology.

Received 5 February 2009, received in final form 30 June 2009. Accepted 10 July 2009.

Dr. Fabiano Reis - Rua Conceição 286 / 26 - 13010-050 Campinas SP - Brasil. E-mail: fabianoreis2@gmail.com 
Surgical specimens and biopsy show typical encephalitis with widespread perivascular cuffs and round cells, gliosis and scattered microglial nodules. However, the morphologic picture of active chronic encephalitis is nonspecific. Resected specimens in the more advanced clinical stages have demonstrated diffuse cortical atrophy with neuronal loss and a lack of inflammatory cells ${ }^{7}$. Magnetic resonance imaging (MRI) in combination with clinical data and slow focal activity on EEG, contralateral to the motor manifestations may indicate the diagnosis ${ }^{8,9}$ and hasten brain biopsy. The progression of lesions on MRI seems to reflect the course of this disease and prognosis, although the extent of the lesions not necessarily correlates with the frequency of seizures ${ }^{10}$.

Thus, the purpose of this study was to determine if MRI may indicate prognosis in patients with RE.

\section{METHOD}

Local research ethics committees granted ethical approval for the study.

Magnetic resonance exams were performed in five patients with clinical and neuroimaging evidences of RE. In three of them the diagnosis of RE was confirmed by pathological examination of the surgical specimen. In the other two, clinical and imaging of two year follow-up confirmed the diagnosis. MRIs were performed in a 2T scanner (Elscint Prestige ${ }^{\circledast}$, Haifa, Israel), with $\mathrm{T} 1$ and $\mathrm{T} 2$ acquisitions in three orthogonal planes, including $\mathrm{T1}-$ weighted SE gadolinium enhanced images. MRI acquisition parameters were: sagital $\mathrm{Tl}$ spin echo, $6 \mathrm{~mm}$ thick, flip angle $=180^{\circ}$; repetition time (TR) $=430 \mathrm{~ms}$, echo time $(\mathrm{TE})=12 \mathrm{~ms}$, matrix 200 $\times 350$, field of view (FOV) $=25 \times 25 \mathrm{~cm}$, T2-weighted and proton density "fast spin echo" (FSE), $3 \mathrm{~mm}$ thick, flip angle $=160^{\circ}$; $\mathrm{TR}=4800 \mathrm{~ms}, \mathrm{TE}=108 / 18 \mathrm{~ms}$, matrix $256 \times 256, \mathrm{FOV}=22 \times 22 \mathrm{~cm}$; T1-weighted spin echo (SE); TR=540 ms, TE=28 ms; Tl-weighted inversion recovery (IR), $3 \mathrm{~mm}$ thick, flip angle $=200^{\circ} \mathrm{TR}=2700 \mathrm{~ms}$, inversion time $(\mathrm{TI})=860 \mathrm{~ms}, \mathrm{TE}=14 \mathrm{~ms}$, matrix $130 \times 256$, field of view (FOV) $=16 \times 18 \mathrm{~cm}$, and T2-weighted fluid-attenuated inversion recovery (FLAIR) images TR=8500 and $2000 \mathrm{~ms}$ or 100 and $2200 \mathrm{~ms}, \mathrm{TE}=72$ or $90 \mathrm{~ms}$, matrix of $256 \times 296$ and FOV of $22 \times$ $22 \mathrm{~cm}$. The analysis of exams, including establishment of atrophy grade, were performed by visual parameters, by three different observers.

Single voxel hydrogen magnetic resonance spectroscopy (' $\mathrm{H}-$ MRS) was acquired in four of the patients, using PRESS sequence ( $T R / T E=1500 / 135 \mathrm{~ms}$, number of excitation ((NEX)=200) with two regions of interest (ROIs) of $8 \mathrm{~cm}^{3}$, one in each parietal deep white matter. Prior to the acquisition, a localized shimming at the ROI was performed, followed by water suppression adjustment. Localized shimming was repeated to ensure good field homogeneity and until the ${ }^{1} \mathrm{H}$ signal from water within the $\mathrm{ROI}$

Table. Patient's data.

\begin{tabular}{|c|c|c|c|c|c|c|c|}
\hline $\begin{array}{l}\text { Patient } \mathrm{n}^{\circ} \\
\text { Sex } \\
\text { Age (years) } \\
\text { Affected } \\
\text { hemisphere }\end{array}$ & Antecedents & $\begin{array}{c}\text { Age of } \\
\text { onset first } \\
\text { symptoms } \\
\text { (years) }\end{array}$ & $\begin{array}{l}\text { Seizures in } \\
\text { evolution }\end{array}$ & $\begin{array}{c}\text { Neurological } \\
\text { outcome }\end{array}$ & $\begin{array}{l}\text { Hyper } \\
\text { signal at } \\
\text { T2 MRI }\end{array}$ & $\begin{array}{c}\text { Hemispheric } \\
\text { and caudate } \\
\text { atrophy }\end{array}$ & Surgery \\
\hline $\begin{array}{l}1 \\
M \\
17 \\
\mathrm{R}\end{array}$ & $\begin{array}{l}\text { Meningitis, } \\
\text { immediately before } \\
\text { the onset seizures }\end{array}$ & $\begin{array}{c}6 \\
\text { GTC }\end{array}$ & $\begin{array}{c}\text { EPC } \\
\text { (left superior } \\
\text { limb, motor) }\end{array}$ & hemiparesis & Yes & Yes & Yes \\
\hline $\begin{array}{c}2 \\
F \\
15 \\
R\end{array}$ & Not important & $\begin{array}{c}10 \\
\text { GTC }\end{array}$ & $\begin{array}{c}\text { EPC } \\
\text { (left limbs, motor) } \\
+\mathrm{GTC}\end{array}$ & $\begin{array}{l}\text { Left foot paresis and } \\
\text { coordination deficits }\end{array}$ & No & Yes & No \\
\hline $\begin{array}{c}3 \\
F \\
16 \\
L\end{array}$ & $\begin{array}{l}\text { Mother's cousin } \\
\text { with epilepsy }\end{array}$ & $\begin{array}{l}9 \text { GTC and } \\
\text { SPMS }\end{array}$ & $\begin{array}{c}\text { EPC } \\
\text { (right limbs, motor) } \\
+\mathrm{GTC}\end{array}$ & $\begin{array}{l}\text { Facial and oral } \\
\text { automatisms and } \\
\text { right coordination } \\
\text { deficits }\end{array}$ & No & Yes & No \\
\hline $\begin{array}{l}4 \\
F \\
7 \\
R\end{array}$ & $\begin{array}{c}\text { Varicella, } 2 \\
\text { months before the } \\
\text { onset seizures }\end{array}$ & $\begin{array}{c}2 \\
\text { SPMS }\end{array}$ & $\begin{array}{c}\text { SPMS } \\
\text { (left superior limb) }\end{array}$ & Hemiparesis & Yes & Yes & Yes \\
\hline $\begin{array}{l}5 \\
M \\
6 \\
L\end{array}$ & $\begin{array}{l}\text { Twin brother } \\
\text { with myoclonus }\end{array}$ & $\begin{array}{c}5 \\
\text { GTC }\end{array}$ & $\begin{array}{c}\text { SPMS } \\
\text { (right limbs) } \\
+ \text { GTC }\end{array}$ & Hemiparesis & Yes & Yes & Yes \\
\hline
\end{tabular}

M: male; F: female; R: right; L: left; GTC: generalized tonic clonic seizure; SPMS: simple partial motor seizure; EPC: epilepsia partialis continua. 
became as narrow as possible. The spectra were post-processed using software supplied by the machine manufacturer (Elscint Prestige 2T, Haifa, Israel).

\section{RESULTS}

Table summarizes clinical, EEG and image findings. The age at onset ranged from 2 to 10 years (mean 6.4 years). In the six months before the first symptom, two patients had infections (measles and meningitis). Tonic-clonic generalized seizures marked disease onset in 4 patients and partial seizures in one patient. Seizure frequency varied, however all five patients presented epilepsia partialis continua (EPC) at some point of the disease. Convulsive status epilepticus occurred in two patients. Three patients developed hemiparesis. In two patients, who developed symptoms at oldest age, the neurological examination remains normal despite slow progression of the hemispheric atrophy. Although cognitive decline is difficult to assess be- cause polypharmacy and frequent seizures, four patients showed some degree of cognitive impairment.

Figure 1 summarizes image findings. All patients had cortical atrophy associated with ipsilateral ventricular enlargement and caudate atrophy, more severe in those with hemiparesis. The most affected areas were insular, temporal and parietal regions. Gray and white matter focal signal intensity abnormalities (hyperintense signal in long TRweighted images) were found in the three patients with hemiparesis.

${ }^{1} \mathrm{H}-\mathrm{MRS}$ performed in one patient (1) showed increased lactate and choline and decreased NAA in atrophic regions (Fig 2). In another patient (3), 'H-MRS did not show differences between hemispheres (Fig 3).

Antiepileptic drugs were only partially effective for seizure control. Plasma exchange was performed in two patients with transient improvement. Three patients with hemiparesis underwent hemispherectomy.

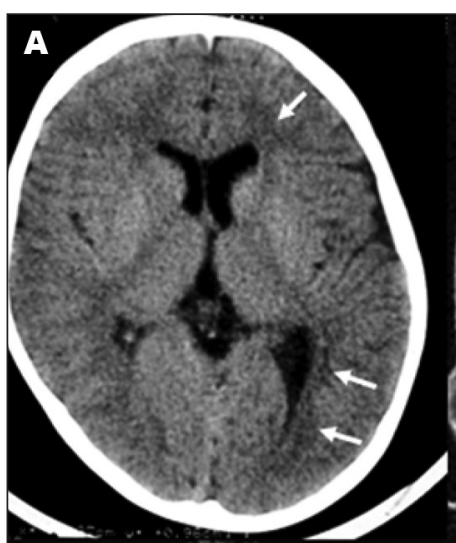

D

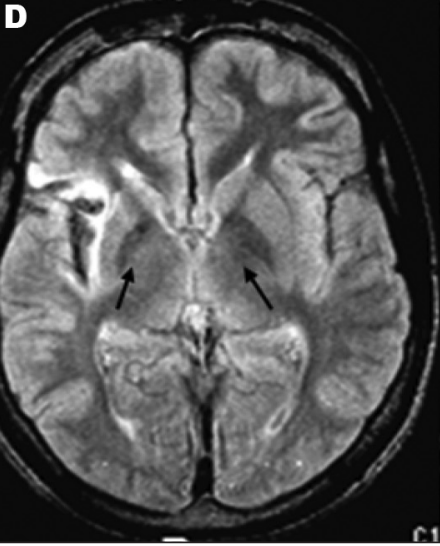

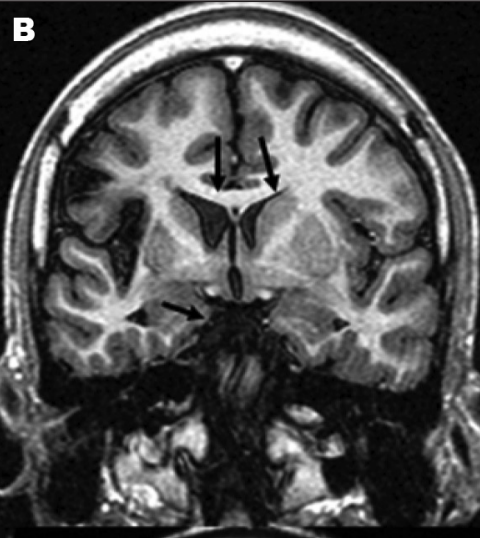

E
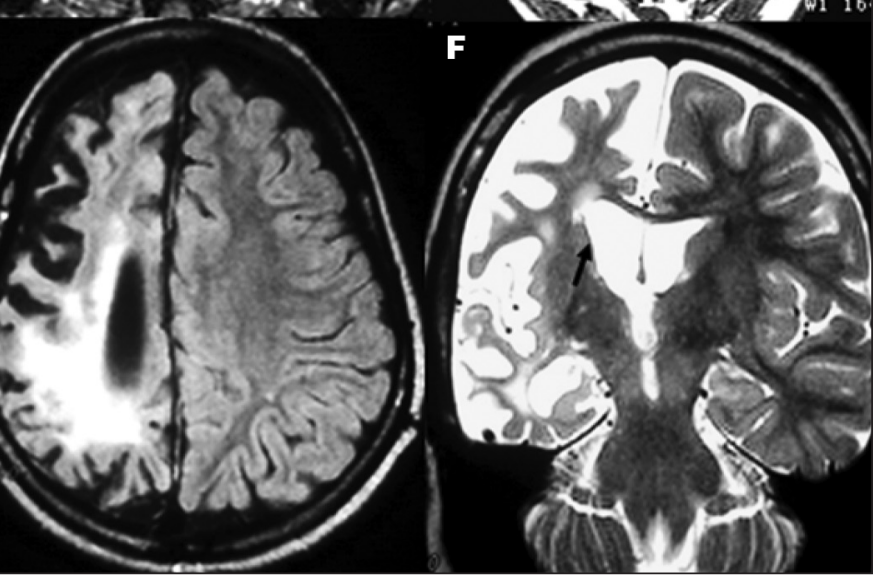

Fig 1. [A] CT. Left hemispheric atrophy with ventricular and cortical sulci enlargement. Note hypodense areas in the white matter of the affected hemisphere (arrow). [B] Coronal T7-weighted image at the level of the anterior commissure. Right hemispheric atrophy. Note the width of right Sylvian fissure, frontal horn and temporal horn of right lateral ventricle (arrow). [C] Coronal IR-weighted image. Asymmetry between head of caudate nucleus, atrophic on the left side (arrow). Note the width of frontal horn of ipsilateral ventricle in consequence of atrophy. [D] Axial T2- weighted image. Hyperintense signal in right insular cortex with discrete width of Sylvian fissure at this level. Note the head caudate nucleus asymmetry (arrows). [E] Axial FLAIR image. Marked right hemiatrophy with hyperintense signal in the white matter of parietal region. [F] Coronal T2-weighted image. Marked right hemiatrophy with focal areas of hyperintense signal in the white matter of frontal, parietal and temporal regions. Note the ipsilateral caudate nucleus atrophy (arrow). 


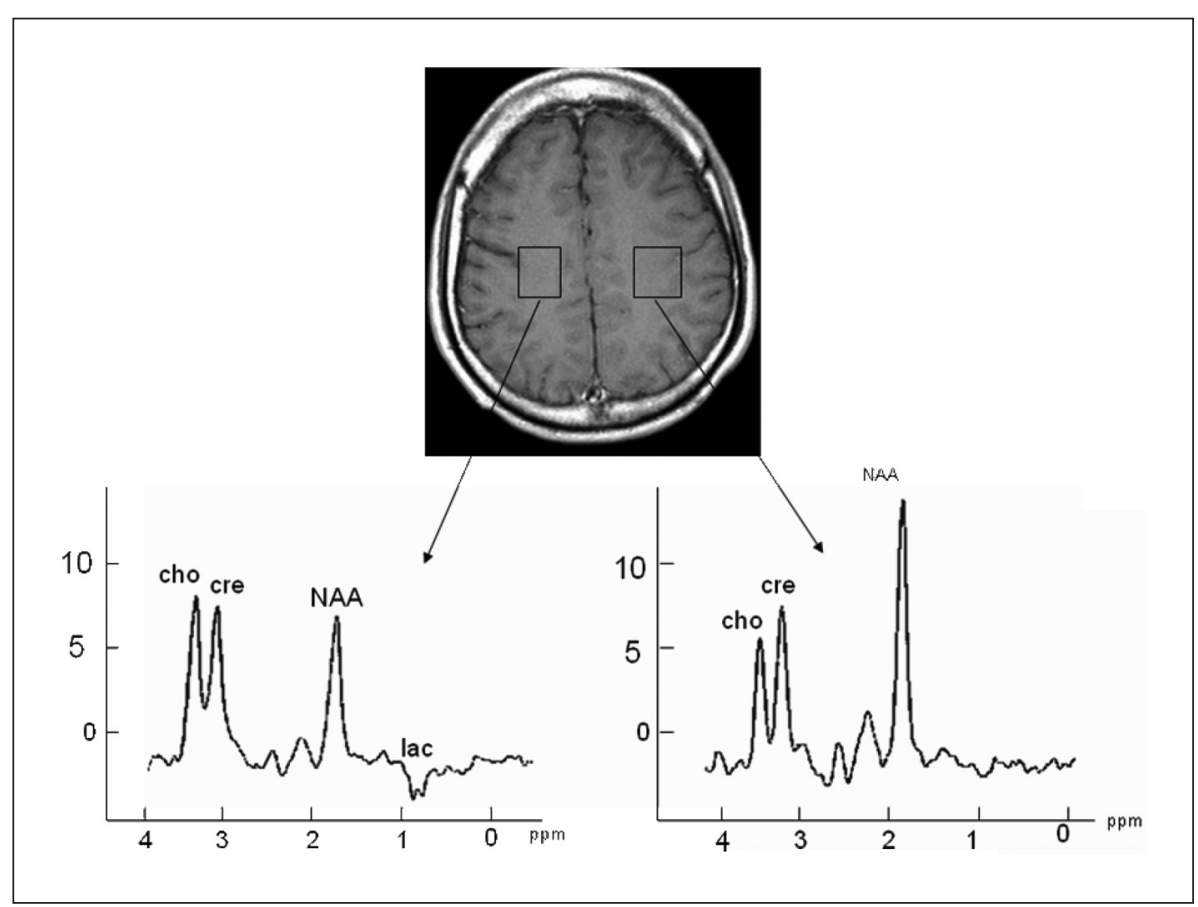

Fig 2. MRS, performed at white matter of frontal regions in patient 1. Note the decreased NAA, increased choline (Cho) and lactate (lac) peak in the atrophic hemisphere (right) compared with the normal one. Cre: creatine.

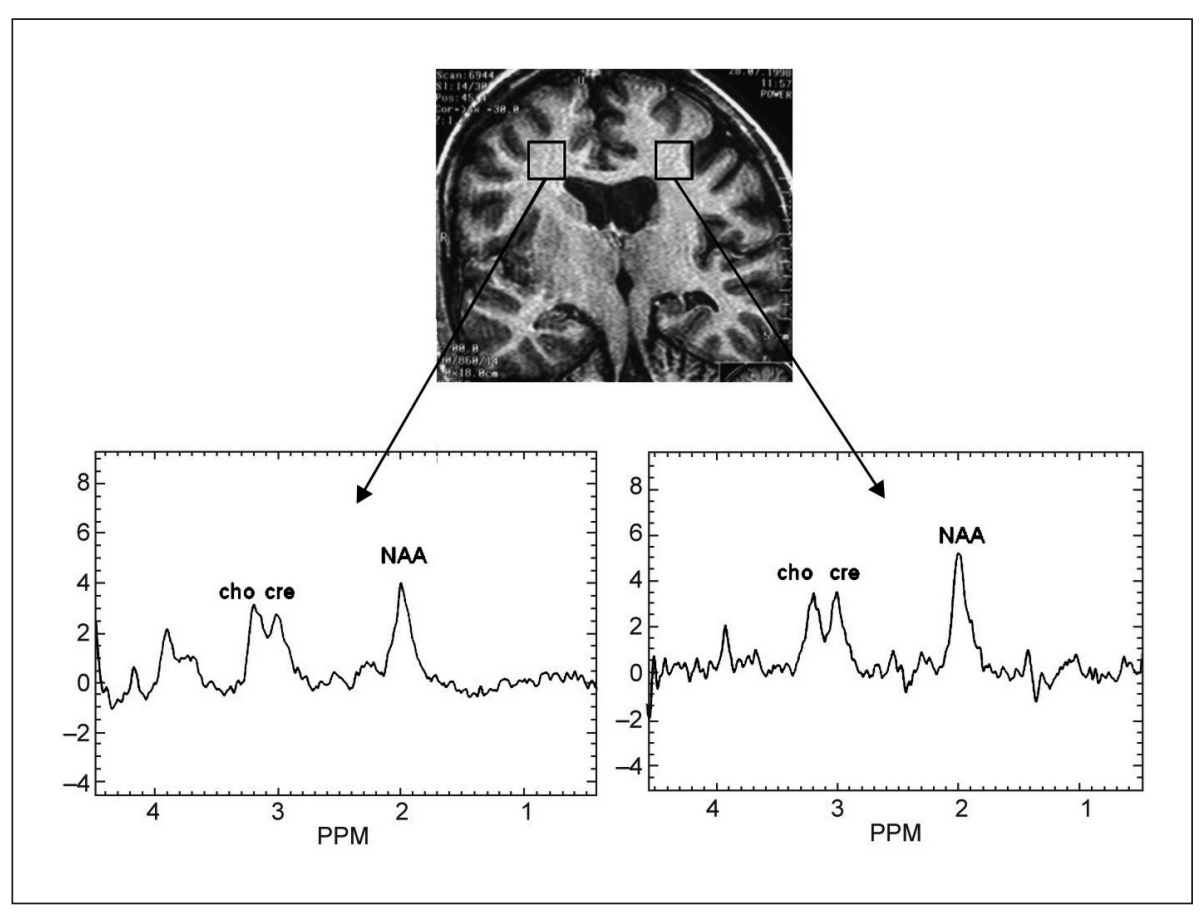

Fig 3. MRS, performed at white matter of frontal regions. There were not differences between the normal side and atrophic hemispheres: right, in patient 3.

\section{DISCUSSION}

Progressive cerebral hemiatrophy associated with clinical deterioration and focal EEG features, was the key to the diagnosis of RE, avoiding brain biopsy in all our pa- tients. The age of onset, the first seizure (generalized tonic-clonic seizure) and a preceding inflammatory or infectious event (that occurred in 2 of 5 of patients), are in agreement with previous studies". 
As occur in RE, seizures were focal, involving exclusively one hemibody, and refractory to antiepileptic drugs. In the initial phase the diagnosis of chronic encephalitis may be difficult, particularly in the absence of EPC. There is a progressive increase in seizure frequency and severity and patients develop permanent neurological deficits contralateral to the affected cerebral hemisphere. The initial MRI scans shows that the inflammatory lesion (hyperintense T2/FLAIR signal) had a monofocal onset ${ }^{12,13}$. The next phase of disease is marked by neurological deterioration and may persist for more than 10 years. In the last phase, characterized by hemiparesis, seizures are not so frequent but motor and mental deterioration continues $^{5}$ sometimes in spite of surgery ${ }^{14,15}$. MRI typically shows hemiatrophy with enlargement of ipsilateral ventricles and subarachnoid spaces ${ }^{16-18}$.

Cortical atrophy occurred in all our patients, probably secondary to the long course of disease. It was visual proportional to the severity of symptoms, most likely reflecting the severity of disease. However, even patients without hemiparesis presented diffuse hemispheric atrophy. We suppose that this can be an example of brain functional plasticity in chronic insults, frequently observed in RE, pre- and post- operatively ${ }^{19,20}$. It is possible that reorganization of somatosensory cortex helps to maintain functions, in spite of the anatomical damage. Caudate atrophy occurred in all our patients, although this has been rarely reported ${ }^{21-23}$.

Patients with hemiparesis and more frequent seizures presented also gray and focal white matter hyperintensity in T2-weighted images. Bien et al. demonstrated that this signal change is correlated with the number of $\mathrm{T}$ cells in brain parenchyma and reactive gliosis, indicating ongoing damage ${ }^{4,24}$. In our study, patients with hyperintense T2 lesions and hemiparesis had the most devastating forms of RE.

${ }^{1} \mathrm{H}$ MRS contributes to evaluation and progression of metabolic changes in $\mathrm{RE}^{9,25-27}$. Although the patterns of metabolites observed are nonspecific. Compared with normal hemisphere, the atrophic regions showed increased lactate, a consequence of repetitive focal epileptic neuronal activity ${ }^{28,29}$, as well as increased choline (related to gliosis, microglial proliferation and elevated membrane turnover ${ }^{30}$ ) and reduced NAA. As NAA plays a role as neuron-glia signaling system ${ }^{31}$, this reduction reflects neuronal loss and axonal dysfunction/depletion ${ }^{32}$ and possibly also changes in neurotransmitter system, altered in $\mathrm{RE}^{33}$. This reduction in NAA suggests ongoing neuronal and axonal damage and loss in RE. Patients 1 and 4, with more severe disease and atrophy, showed these abnormalities (Fig 2, related to patient 1). Particularly, the lactate increase was related with recent crisis (not controlled) and not to the disease itself.
In the two patients (patients 2 and 3, Table) whose ${ }^{1} \mathrm{H}$ MRS did not showed differences between hemispheres (patient 3, Fig 3), the MRI did not show abnormal signal but only atrophy, the age of onset was more advanced and the crisis were controlled with drugs, without surgery, showing a positive correlation between metabolic and structural changes and severity of disease.

Parenchyma atrophy was a common finding of RE in our group and even patients without hemiparesis had some degree of hemispheric atrophy. Our hypothesis is this disconnection is related with the plasticity of child's brain, but a greater number of cases and application of functional techniques, as $\mathrm{fMRI}$, are needed to confirm it. In spite of the few number of patients, we noticed a tendency of patients with more severe disease to present signal changes on MRI and abnormal MRS. This finding may thus favor the possible existence of biochemical changes underlying structural damage, not necessarily visible on conventional MRI. These data are preliminary and these theses will be verified expanding the group and the follow-up timing.

\section{REFERENCES}

1. Rasmussen T, Olszewski J, Lloyd-Smith D. Focal seizures due to chronic localized encephalitis. Neurology 1958;8:435-445.

2. Rogers SW, Andrews PI, Gahring LC, et al. Autoantibodies to glutamate receptor GluR3 in Rasmussen's encephalitis. Science 1994;265: 648-651.

3. Krauss GL, Campbell ML, Roche KW, Huganir RL, Niedermeyer E. Chronic steroid-responsive encephalitis without autoantibodies to glutamate receptor GluR3. Neurology 1996;46:247-249.

4. Bien CG, Bauer J, Deckwerth TL, et al. Destruction of neurons by citotoxic T cells: a new pathogenic mechanism in Rasmussen's encephalitis. Ann Neurol 2002;51:311-318.

5. Granata T, Gobbi G, Spreafico R, et al. Rasmussen's encephalitis: early characteristics allow diagnosis. Neurology 2003;60:422-425.

6. Korn-Lubetzki I, Bien CG, Bauer J, et al. Rasmussen encephalitis with active inflammation and delayed seizures onset. Neurology 2004;62: 984-986.

7. Rasmussen T, Andermann F. Update on the syndrome of "chronic encephalitis" and epilepsy. Cleve Clin J Med 1989;56:181-184.

8. Chiapparini L, Granata T, Farina L, et al. Diagnostic imaging in 13 cases of Rasmussen's encephalitis: can early MRI suggest the diagnosis? Neuroradiology 2003;45:171-183

9. Geller E, Faerber EN, Legido A, et al. Rasmussen encephalitis: complementary role of multitechnique neuroimaging. Am J Neuroradiol 1998;19:445-449.

10. Nakasu S, Isozumi T, Yamamoto A, Okada K, Takano T, Nakasu Y. Serial magnetic resonance imaging findings of Rasmussen's encephalitiscase report. Neurol Med Chir 1997;37:924-928.

11. Mattheus PM, Andermann F, Arnold DL. Proton magnetic resonance spectroscopy study of chronic encephalitis and epilepsy. In: Andermann F (Ed). Chronic encephalitis and epilepsy: Rasmussen's syndrome. Boston: Butterworth-Heinemann, 1991:73-77.

12. Bien CG, Widman $G$, Urbach $H$, et al. The natural history of Rasmussen's encephalitis. Brain 2002;125:1751-1759.

13. Maeda Y, Oguni H, Saitou Y, et al. Rasmussen syndrome: multifocal spread of inflammation suggested from MRI and PET findings. Epilepsia 2003;44:1118-1121.

14. Kim SJ, Park YD, Pillai J. What is the fate of disconnected brain tissue in a child with Rasmussen syndrome? A case report. Neuroradiology 2003;45:250-252. 
15. Thomas P, Zifkin B, Ghetâu G, Delalande O. Persistence of ictal activity after functional hemispherectomy in Rasmussen syndrome. Neurology 2003;60:140-142.

16. Lutkenhoner B, Menninghaus E, Steinstrater O, Gissler HM, Elbert T. Neuromagnetic source analysis using magnetic resonance images for the construction of source and volume conductor model. Brain Topogr 1995;7:291-299.

17. Takeoka M, Kim F, Caviness VS Jr, Kennedy DN, Makris N, Holmes GL. MRI volumetric analysis in Rasmussen encephalitis: a longitudinal stydy. Epilepsia 2003;44:247-251.

18. Larionov S, König R, Urbach H, Sassen R, Elger CE, Bien CG. MRI brain volumetry in Rasmussen encephalitis: the fate of affected and "unaffected" hemispheres. Neurology2005;64:885-887.

19. Hertz-Pannier L, Chiron C, Jambaque I, et al. Late plasticity for language in a child's non-dominant hemisphere: a pré- and post-surgery fMRI study. Brain 2002;125:361-372.

20. Ishibashi H, Simos PG, Wheless JW, et al. Multimodality functional imaging in a patient with Rasmussen's encephalitis. Brain Dev 2002;24:239-244.

21. Bhatjiwale MG, Polkey C, Cox TC, Dean A, Deasy N. Rasmussen's encephalitis: neuroimaging findings in 21 patients with a closer look at the basal ganglia. Pediatr Neurosurg 1988;29:142-148.

22. Koehn MA, Zupanc ML. Unusual presentation and MRI findings in Rasmussen's syndrome. Pediatr Neurol 1999;21:839-842.

23. Fogarasi A, Hegyi M, Neuwirth M, et al. Comparative evaluation of concomitant structural and functional neuroimages in Rasmussen's encephalitis. J Neuroimaging 2003;13:339-345.
24. Bien CG, Urbach H, Deckert M, et al. Diagnosis and staging of Rasmussen's encephalitis by serial MRI and histopathology. Neurology 2002; 58:250-257.

25. Sener RN. Rasmussen's encephalitis: proton MR spectroscopy and diffusion MR findings. J Neuroradiol 2000;27:179-184.

26. Sener RN. Diffusion MRI and spectroscopy in Rasmussen's encephalitis. Eur Radiol 2003;13:2186-2191.

27. Wellard RM, Briellmann RS, Wilson JC, et al. Longitudinal study of MRS metabolites in Rasmussen encephalitis Brain 2004;127:1302-1312.

28. Cendes F, Andermann F, Silver K, Arnold DL. Imaging of axonal damage in vivo in Rasmussen's syndrome. Brain 1995;118:753-758.

29. Duprez TP, Grandin C, Gadisseux JF, et al. MR-monitored remitting-relapsing pattern of cortical involvment in Rasmussen syndrome: comparative evaluation of serial MR and PET/SPECT features. J Comput Assist Tomogr 1997;21:900-904.

30. Castillo M, Kwock L, Mukherji SK. Clinical aplications of proton MR spectroscopy. AJNR Am J Neuroradiol 1996;17:1-15.

31. Petroff OAC, Errante LD, Kim JH, Spencer DD. N-acetyl-aspartate, total creatine, and myo-inositol in the epileptogenic human hippocampus. Neurology 2003;60:1646-1651.

32. Mathews PM, Andermann F, Arnold DL. A proton magnetic resonance spectroscopy study of focal epilepsy in humans. Neurology 1990;40: 985-989.

33. Gibbs JW, Morton LD, Amaker B, Ward JD, Holloway KL, Coulter DA. Physiological analysis of Rasmussen's encephalitis: patch clamp recordings of altered inhibitory neurotransmitter function in resected frontal cortical tissue. Epilepsy Res1998;31:13-27. 